\title{
Flood Disaster Management in Malaysia: An Evaluation of the Effectiveness Flood Delivery System
}

\author{
Mohamad Sukeri Bin Khalid and Shazwani Binti Shafiai
}

\begin{abstract}
This paper describes the issues relating to the role of the delivery system provided by the government to the flood victims in Malaysia, pre-disaster, during and post-disaster caused by flooding. Presently, the delivery system in flood management was predominantly an official strategy based on a technology centered approach emphasizing the application of new technologies in flood control, forecasting, warning and evacuation systems. In Malaysia, the National Security Council (MKN) has responsibility for controlling the national disaster management system and this organisation will provide an effective relief machinery for recovery following flooding disaster. Further to that, this paper will attempt to describe the type of flood delivery system that has been used in Malaysia and to draw comparisons with delivery systems in other countries.
\end{abstract}

Index Terms-Flood management approach in Malaysia, flood delivery system.

\section{INTRODUCTION}

In Malaysia, flooding has affected many areas since 1971. Because of that, the Government established the Natural Disaster Management and Relief Committee (NDMRC) in 1972, it was given the task of coordinating flood relief operations at every stage of national, state and district levels with the combined aims of reducing flood damage and to preventing loss of human life. Flood disaster management in Malaysia is based on the National Security Council (NSC) Directive No.20 and Fixed Operating Regulations (PTO). These were outlining the aims of Policy and Mechanism on Disaster and Relief Management on Land. This directive also describes the purpose of responsibilities and determining how the various agencies should be involved in disaster management.

Disaster management in Malaysia has three levels and every committee in every level has its own responsibility. In level I, the committee ensures coordinated actions, with sufficient asset and human resources, in relation to the media. Level II, must provide to the District assistance such as financial aid, assets and human resources. For the third level, the committee must determine the national disaster management policy, finance, assets and human resources. The three levels are shown below in Table I [1].

\footnotetext{
Manuscript received October 25, 2013; revised January 13, 2014. This work was supported in part by the Ministry of Higher Education Malaysia under the Long Term Research Grant Scheme (LRGS/b-u/2012/UUM/Communication Technology and Information).

Mohamad Sukeri Bin Khalid and Shazwani Binti Shafiai are with the School of Law, Government and International Studies, Universiti Utara Malaysia, Malaysia (e-mail: sukeri@uum.edu.my, shazwani.shafiee@yahoo.com).
}

TABLE I: DisASTER MANAGEMENT LEVEL /EXECUTIVE COMMITTEE

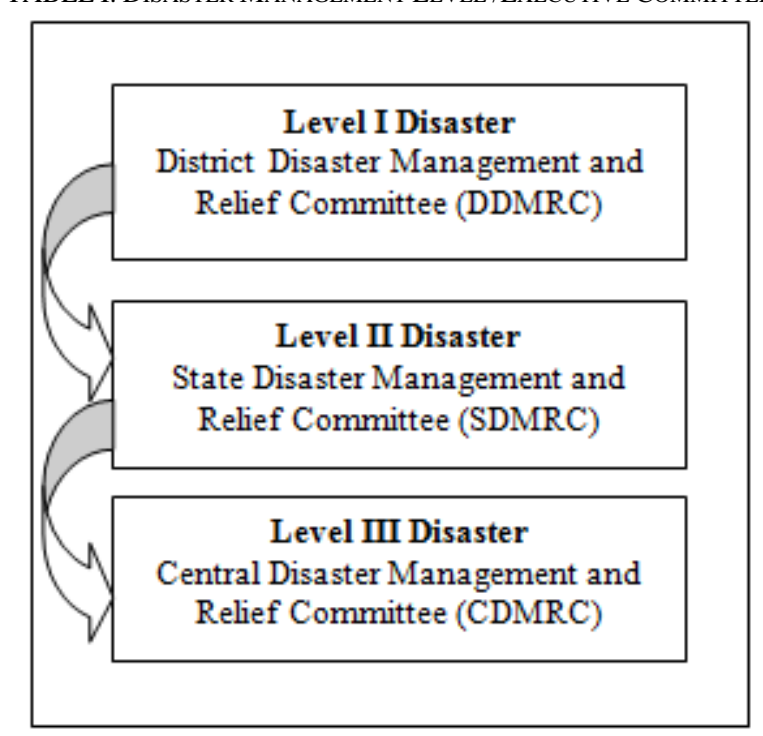

Source: National security council (2011).

In 2010, Malaysia experience serious flooding which had a negative impact on several states especially on the economy and to society in general. The average rainfall for all states in Malaysia is approximately $2,500 \mathrm{~mm}$ a year, making it the one of the countries with the heaviest rainfall in the world.

In addition, most people in Malaysia are less concerned about environmental issues especially disasters, because they think that the issue is a trivial issue which should be resolved by the district or local authority, and they expect the government to be the sole provider of flood protection when the flooding occur. Obviously people will respond to disasters, applying one of four options to accommodate, to protect, to retreat and to do nothing. It can be see that the ways of human adjustment to flooding are naturally different according to region as natural environment; national economy; people's living patterns and social structures are all different [2].

Hence, governments or authorities have developed the floods delivery system for quicker recovery in order to reduce flood losses and give early warning of the likelihood of flooding. The delivery system generally outlines procedures of government services to implement the government administration for communities, to be more consistent and effective. Furthermore, the delivery system is a procedure for providing a service or product to the public.

In flood management, the roles of delivery systems were the methods to be used in a holistic manner for giving information and assistance for every phase. In Malaysia, the Government has implemented the important role of the delivery system after a flood disaster has occurred. According to the Ministry of Natural Resources and 
Environment, earlier experience has shown that the most effective approach is through the development of flood management programs using a holistic approach with respect to the following five strategies:

1) Prevention-avoiding construction of houses, properties and industries in present and future flood- prone areas for preventing damage caused by floods;

2) Protection-to reduce the likelihood and the impact of floods in a specific location, with the Government taking structural and non-structural measures;

3) Preparedness-to give information to the public about what to do in the event of flooding and about flood risks;

4) Emergency Actions-in case of flood, developing the emergency response, formulate plans and actions;

5) Recovery and lessons learned-after flooding disaster, return to normal conditions as soon as possible and mitigate both social and economic impact [3].

According to this strategy, the collaboration of government, private sector, Non Governmental Organization (NGO) and community in general is the most important factor to achieve the flood delivery system in Malaysia. Apart from that, the success of disaster management depends on its implementation in the local areas; this can reduce the impact of disaster on the affected communities. However, the communities themselves based on education about and awareness of disaster risk management, could also lead to a reduction of the impact of disaster.

\section{Phases of The Flood Delivery System in Malaysia}

Delivery system is one important mechanism which will be used and it is one of the flood policies used by the Government in the management of non-structure measures [4]. The classified stages of disaster management are categorized into the pre-disaster risk reduction and post-disaster recovery phases. The most sensitive part is the last stage of the pre-disaster risk reduction phase, because its negligence will undoubtedly directly lead to devastating effects on the residents of the disaster-vulnerable areas [5].

Further to that, the committee of NDMRC was entrusted with the responsibility of planning, coordinating and supervising relief operations during flooding. This committee includes governmental departments and agencies, and social organizations that are able to provide rescue, shelter, food and medical supplies for the victims. Furthermore, in the case of flooding, the National Crisis and Disaster Management Mechanism (NCDMM) would be called the National Flood Disaster Relief Machinery (NFDRM). The NFDRM reacts to major floods when they occur, and is basically a reactive system. The NFDRM is theoretically responsible for operations at national, state, district, mukim and village levels [6].

In the event of flooding, the Government has developed the relief machinery and emergency flood management, and for post-disaster, funding and aid delivery systems to help the victims recover after disaster occurs.

\section{A. Flood Forecasting and Warning System (Pre-Disaster)}

Flood forecasting and warning system constitutes an effective and economical means to reduce losses of lives, trauma of disaster and property damage. An early warning system is important mechanism which can give timely and effective information through identified institutions, that allows individuals exposed to hazard to take action, avoid or reduce their risk and prepare for effective response [7].

The Department of Irrigation and Drainage Malaysia (DID) is responsible for providing flood forecasting and warning services to the public [6]. Available records showed that flood warning services were first provided for the flood event of 1925 when floods occurred along the Kinta River in Perak and Klang River in Selangor and Bernam River in Selangor and Perak Boundary [3].

The purpose of preparedness is to reduce the residual risk through early warning systems and measures which can be taken to mitigate the effect of a flood disaster [8]. At present, the short messages system (SMS) is provided to give an alert to relevant officers in-charge of government agencies such as Police, Army, the Malaysia Meteorological Department (JPA3), DID, and National Security Division (BKN) at Prime Minister's Department. The SMS delivery system should also be extended to the community because the information about a flood event will reach them more effectively [5]. This statement is supported by Sahu (2006), because SMS is an effective notification system, able to be used to communicate to a larger percentage of people and its functional resilience to disaster. However, the message must be in the language understood by the target audience, especially in rural areas [9].

Moreover, the real time information of rainfall and river water levels is published on-line via the Infobanjir webpage; this could be directly accessed by the public and governmental officials. The public Infobanjir system enables effective early flood warning dissemination to the public through internet access anywhere and at any time [10].

Undoubtedly, according to Chan, Zakaria, Ghani, and Lien, (2004), the authorities should also look at improvement of flood forecasting. Often, sophisticated flood warning and evacuation system (FWESs) are alien to the public who are accustomed to traditional FWESs [11]. This will happen because of lack of confidence and mistrust in the costly new technologies [12].

Hence, the flood forecasting and warning system have been upgraded. By 2007, the following infrastructure for flood forecasting and warning systems had been installed: 233 telemetric rainfall stations; 190 telemetric water level stations; 256 manual stick gauges; 84 flood warning boards; 217 flood sirens; real time flood forecasting and warning systems in nine river basins [6].

Further to that, the operational flood forecasting systems form a key part of 'preparedness' strategies for disastrous flood events by providing early warnings several days ahead, giving flood forecasting services, civil protection authorities and the public adequate preparation time, thus reducing the impacts of the flooding [13].

\section{B. Flood Relief Machinery (During Disaster)}

In Malaysia, disaster management is almost entirely based on a top-down approach and the relief operation is the responsibility of the Natural Disaster Relief Committee. This machinery was established with the objective of 
co-coordinating relief operations at federal, state and district levels in order to provide assistance to flood victims in an orderly and effective manner. At least once a year, normally before the northeast monsoon, the committee will meet to ensure that its machinery will run smoothly [14].

In accordance with the operating procedures under the flood relief mechanism, the DID begins to monitor closely the flood situation when the river stage of the flood warning station reaches the 'alert' level and the DID will advise the relevant flood control centers that the flood relief mechanism shall be activated. The respective state DID office must carry out the flood forecast operation using the real time telemetric data and river forecasting computer models during the flood season. When the river water level at any forecasting point exceeds the critical level, the forecast must be transmitted to the flood operation centers and other relevant agencies such as the National Security Division of the Prime Minister's Department and the national and state control center for flood relief and operation [3].

From the above, it is seen that all the machinery has its their own responsibility to convey its delivery system for victims when flooding occurs.

\section{Flood Management Emergency (During Disaster)}

When the flooding occurs, the victims need assistance to transfer them from the flood zone. The flood mitigation infrastructure and the flood warning system may be damaged right at the start of the flooding event [3].

Therefore, the flood operation during the disaster requires close cooperation and understanding among various parties involved at the flood plain including coordination district level to be efficient and successful in rescuing victims and reduction of property losses. This will create chaos and additional dangers in the flood rescue operations, especially when both road transport and telecommunications are disrupted and electricity supply is short-circuited at the start of the flood and rescue operations must continue throughout the night. Obviously, the flood emergency response to rescue the victims is led by Army and Public Defense Services [15].

Because of that, an advanced and accurate flood warning information system provided in a timely manner before and throughout the flood duration, will also help to reduce the number of flood victim deaths, trauma and property damages. Flood hazard maps should be produced early and disseminated to the public before hand to help and guide the flood victims to safety in the fastest possible routes when flooding occurs [3].

\section{Funding and Aid Delivery System (Post-Disaster)}

The effectiveness of policy implementation and the assistance provided in a timely manner can provide an immediate impact on the victims [16]. The aid delivery system for flood victims in Malaysia is based on two forms: financial and non-financial assistance [17].

A tremendous amount of financial allocation, in areas such as physical infrastructure development, will be needed to carry out an effective flood management strategy. This includes the construction of large dams, canalization of rivers and building high capacity sewage treatment plants to restore polluted rivers to their original clean water quality condition.
In the events of flooding from November 2010 to April 2011, the total delivery of assistance given by the Government to victims can be seen in Table II [1].

TABLE II: TOTAL ASSISTANCE FOR NOVEMBER 2010 - APRIL 2011

\begin{tabular}{|c|l|l|l|l|}
\hline No & \multicolumn{1}{|c|}{ State } & $\begin{array}{c}\text { Approval of } \\
\text { Origin } \\
\text { To } \\
\text { KWABBN } \\
(\mathrm{RM})\end{array}$ & $\begin{array}{c}\text { Total } \\
\text { Distributed } \\
(\mathrm{RM})\end{array}$ & $\begin{array}{l}\text { Victims of } \\
\text { Receiving }\end{array}$ \\
\hline 1. & Kelantan & 84,500 & 82,500 & 165 \\
\hline 2. & Terengganu & 716,500 & 684,500 & 1369 \\
\hline 3. & Perlis & $10,287,000$ & $8,612,000$ & 17,224 \\
\hline 4. & Kedah & $30,250,000$ & $20,405,000$ & 40,810 \\
\hline 5. & Johor & $25,368,500$ & $14,201,500$ & 28,358 \\
\hline 6. & Melaka & $1,167,500$ & $15,000.00$ & 21 \\
\hline 7. & Pahang & 231,500 & $229,000.00$ & 458 \\
\hline 8. & Sabah & 343,000 & $325,500.00$ & 624 \\
\hline 9. & $\begin{array}{l}\text { Negeri } \\
\text { sembilan }\end{array}$ & 521,000 & 521,000 & 1042 \\
\hline & \multicolumn{5}{|c|}{ TOTAL } & $45,076,000$ & 90,071 \\
\hline
\end{tabular}

Source: National security council, (2011).

\section{FlOOD DELIVERY SYSTEM IN THAILAND}

2010 and 2011 were tragic years for Thailand. After the political turmoil in May 2010, flooding hit different parts of Thailand incessantly in regions such as Bangkok, Chiang Mai and Hat Yai from October 2010 towards the end of 2011[18]. Obviously, flood in Thailand rarely causes by typhoons, normally by tropical storm and depressions. This natural hazard which affected population quality of life and country economy. Thailand certainly already has a flood policy, but that policy was not capable of facing this disaster.

Thailand has the National Forecasting and Warning center, but the structural engineering cannot completely overcome that's flood. This is because no matter high standard of the design, there is always the possibility of higher floods exceeding the standard [19]. The improvement of an early warning system and emergency response can be seen to reduce loss of life, but the enhancement of property, as well as reducing risk to livestock and crops will present serious challenges to flood management [20].

In addition, flood disaster in 2011 causes by insufficient of flood prediction system, not on time flood warning system because of overflow phenomenon, unsystematic flood fighting system, irregular facilities maintenance, and last but not least, unsystematic of social and political involvement [21].

This disaster also led to increasing frustration and anger when Yingluck failed to overcame this problem while not trying to obtain international assistance [22]. According to Bland B. (2011), the victims blamed the government for not taking more preventive measures and for releasing confusing information [20].

Furthermore the weakness of the flood delivery system in Thailand led to the failure to solve this problem properly because Thailand has a history of corruption in the government's flood relief management [18].

Today, Thailand which more ready to face with this disaster because they already has the Thailand flood 
sensorweb. This mechanism is under Thailand Hydro Agro Informatics Institute (HAII) and they has the important role to get the numerous rainfall, water level and flow rate sensor [23].

Apart from that, Thailand Government has set up strategic flood committee for short and long term measures to counter with future floods. The flood preventive measure is focus on the upstream plan (to reforestation and build new reservoirs), midstream plan (to prepare for flood plain management), downstream plan (to manage the land use plan and control the development and consider flood way to the sea), administrative aspect (to set up single command organization, with compensation regulations, data base, prediction and warning system), and last is focus to social aspect (to facilitate the understanding, acceptance and participation to the government measures [21].

Thailand lessons learned from flood 2011 and made the improvement to reduce and prevent flood damage in the county.

\section{Flood DELIVERY SYSTEM IN THE UNITED STATES OF AMERICA (U.S.A.)}

The United States of America is a developed country with an efficient and effective policy in dealing with disasters. One of the important events that proved the efficiency of the Government was the assistance provided following the September 11 event. Unfortunately, this action was not matched when Hurricane Katrina hit New Orleans in 2005 [24].

Hurricane Katrina caused economic losses estimated to be more then $\$ 200$ billion, the highest for any disaster in U.S history. According to Burby (2006), the paradox of development by President and Congress is not likely to change because they want to pursue development without considering the risk when disaster occurs [25]. When Hurricane Katrina hit New Orleans, President George W. Bush was criticised because the federal government failed to deliver relief to the victims [24].

In addition, each major U.S disaster brings another tale of corruption and failure within the Federal Emergency Management Agency (FEMA) and yet another Congressional investigation into the problem in FEMA [26]. The FEMA did not provide assistance as expected when Hurricane Katrina occurred indeed, without waiting for FEMA's permission, the Canadian search and rescue team from Vancouver arrived to give assistance to victims in New Orleans days before FEMA's coordinated units. This happen because of which in the case of disaster relief is the president, who must declare a disaster before FEMA act [26].

The different political beliefs between the President and the flood victims caused discrimination and bias, because the President deliberately delayed the disaster declaration and provision of aid to the victims. The procedure for obtaining the assistance began only after the Mayor asked the President for assistance. Therefore, assistance could not be provided immediately to the disaster victims [24].

In addition, the National Flood Insurance Program (NFIP) will more burden of responsibility for insurance coverage is born by local government [27]. NFIP was created by U.S
Congress in 1968 to provide flood insurance protection for topical storm, hurricanes, and heavy rain [27] [28]. NFIP is provide mainly by the government, and private insurance played are large role in selling and servicing policies [28] Apart of that, NFIP produces floodplain maps, designating risk in different flood zones and set the deductibles and premium for victims [27]. Nowadays, NFIP become the longest standing government-run disaster insurance programs in the world [28].

However, the NFIP has faces certain challenges such as in 1986, NFIP has been rolling over expenses year after year [27]. NFIP also faces with outdated flood-risk maps, low insurances penetration and retention, lack of motivation by residents to invest in risk protection measures, repetitive losses for large claims and NFIP need to sustainable financially to face the truly catastrophic losses [28]. Even the victims expect the federal government to help aftermath to disaster, so they feel that, they do not need to purchase as much insurance as they would otherwise [28]. This is because, the contacts of flood insurance program is just for one years and not for multiyear [28].

And now Flood Insurance Reform Act of 2012 by FEMA already changes the way NFIP is run such as reflect true flood risk, make the program more financially stable, and change how Flood Insurance Rate Map (FIRM) updates the impact to policyholder [29].

This case has shown that the aid delivery system from the Government was too slow and caused the victims to be frustrated with the Government when Hurricane Katrina occurs. But, NFIP is part of the program to reduce victims burden and makes a risk protection for them. This shows that, the government has the way to help peoples when the disaster occurs.

\section{CONCLUSION}

Every country has its own resolution to deal with disaster. Malaysia has its methods which can be used in a holistic manner for giving information and assistance pre-disaster, during and post-disaster, when flooding occurs in the flood-prone areas. Malaysia need to improve pre-disaster delivery system to prevent the negative impact and flood damage in the future because of changing climate with different pattern.

Thailand is Asia country that faces with biggest disaster on 2011 flooding. They already have the flood prevention and flood policy, but when this situation occurs, that mechanism not more suitable. After that experiences, the Government make the improvement and learned from 2011 flooding and create short and long term measure to counter with future flood. On the other hand, in 2011 flooding it looks like victim suffer with government impression with this disaster. This is because, the aid delivery system cannot be provided by the government because of too much corruption in this country. However, the Government will learn from that situation and make a proper plan in the future.

In addition, the United States did have an effective and efficient resolution for dealing with disaster. However, when Hurricane Katrina hit New Orleans, the U.S. Government did not take proper responsibility to face this disaster. Apart from 
that, the discrimination among the victims made the aid delivery system in consistent, and the delay in the disaster declaration caused the victims to become frustrated with the Government. However, their government already has NFIP to help their peoples to cover disaster losses.

For those, flood victims who could not determine when flooding might occur, there were more extensive consequences arising from a lack of preparation and an inability to save their property. However, they learned from this situation that they need to pay more attention and carefully concentrate on the flood warning delivery system.

Besides, the Government must play an important role in providing effective services for flood victims.

\section{REFERENCES}

[1] M. K. Negara, Laporan Kesiapsagaan Bencana Semasa Mosun Timur Laut Malaysia, 2011.

[2] K. Takeuchi, "Flood management in japan-from rivers to an basin," International Workshop on Non-structural Measures for Water Management Problems, pp. 37-44, 2001.

[3] H. A. Hussaini, "Flood and drought management in Malaysia," Ministry of Natural Resources and Environment, Malaysia, Kuala Lumpur, speech given on 21 June 2007.

[4] N. W. Chan and D. J. Parker, "Response to dynamic flood hazard in peninsular Malaysia," in Proc. the Geographical Journal, vol. 162, no. 3, pp. 313-325, November, 1996.

[5] A. S. Ayobami and S. Rabi'u, "SMS as a rural disaster notification system in Malaysia: A feasibility," International Conference on Communication and Media (i-Come'12), 2012.

[6] N. W. Chan, "Impacts of disasters and disasters risk management in Malaysia: the case of floods," in Economic and Welfare Impacts of Disasters in East Asia and Policy Response, Y. Sawada and S. Oum (eds), ERIA Research Project Report 2011-8, Jakarta: ERIA, pp. 497-545, 2012.

[7] S. B. Liong. (2011). Multi-Hazards Early Warning System in Disaster Risk Reduction. Malaysian Meteorogical Department. [Online]. Available: http://www.met.gov.my

[8] E. J. Plate, "Flood risk and flood management," Journal of Hydrology vol. 267, pp. 2-11, 2002.

[9] S. Sahu, "Guidebook on technologies for disaster preparedness and mitigation," Asian and Pacific Centre for Transfer of Technology (APCTT), 2006.

[10] H. M. Noor, H. Ghazali, and F. Mustapha, "Public INFOBANJIR: towards people centered flood information dissemination," Water Resources and Hydrology Division: Department of Irrigation and Drainage Malaysia, ID: 122, 2012.

[11] N. W. Chan, N. A. Zakaria, A. A. Ghani, and T. Y. Lien, "Integrating Official and Traditional Floos Hazard Management in Malaysia," in Proc. $1^{\text {th }}$ International Conference on Managing Rivers in the $21^{\text {st }}$, Century: Issues and Challenge, 2004.

[12] N. W. Chan, "Flood disaster management in Malaysia: An evaluation of the effectiveness of government resettlement schemes," Disaster Prevention and Management, vol. 4, no. 4, pp. 22-29, 1995.

[13] H. L. Cloke and F. Pappenberger, "Ensemble flood forecasting: A review," Journal of Hydrology, vol. 6, no. 5, 2009.

[14] C. W. Chia. (June-August, 2004). Managing Flood Problems in Malaysia. The Ingenieur Bulletin 22. Kuala Lumpur: Board of Engineers Malaysia. [Online]. pp. 38-43. Available: http://www.bem.org.my

[15] A. Shafie, "Extreme flood event: A case study on floods of 2006 and 2007 in Johor, Malaysia," Civil Engineering Department, Colorado State University Fort Collins, 2009.

[16] J. D. Rivera and D. M. S. Miller, "Continually neglected: situating natural disasters in the African American experiences," Journal of Black Studies, vol. 37, no. 4, pp. 502-522, 2007.
[17] M. S. Khalid, A. R. Anuar, M. Jalil, and M. Razani, "Sistem pengurusan bencana di Malaysia: kajian kes banjir," in Proc. International Conference on Economic Regional Development, Law and Governance in Malaysia and Indonesia, 2010.

[18] S. Chingchit, "Thailand floods: not enough to destroy the government," Portuguese Institute of International Relations and Security (IPRIS), 2011.

[19] J. Tospornsampan, "Thailand country report: flood forecasting and warning system in Thailand," $4^{\text {th }}$ Annual Mekong Flood Forum, Siam Reap, Cambodia, 2006.

[20] L. Lebel, T. Foran, P. Garden, and J. B. Manuta, "Adaptation to climate change and social justice: challenges for flood and disaster management in Thailand," 2009.

[21] S. Koontanakulvong, Thailand Floods 2011: Cause and Future Management System, 2012

[22] B. Bland. (2011). Thai anger at government flood response. Nonthaburi Province. Financial Times. [Online]. Available: http://www.ft.com

[23] S. Chien, J. Doubleday, D. Mclaren, D. Tran, V. Tanpipat, R. Chitradon, S. Boonya-aroonnet, P. Thanapakpawin, C. Kunboa, W. Leelapatra, V. Plermkamon, C. Ragavendra, and D. Mandl, "Combining space-based and in-situ measurements to track flooding in Thailand," in Proc. IEEE International, Geoscience and Remote Sensing Symposium, Vancouver, BC. pp. 3935-3938, 2011.

[24] A. Reeves, "Political disaster: unilateral powers, electoral incentives, and presidential disaster declarations," The Journal of Politics, vol. 73 , no. 4, pp. 1142-1151, 2011.

[25] R. J. Burby, Hurricane Katrina and the paradoxes of government decision for hazardous areas," The ANNALS of the American Academy of Political and Social Sciences, pp. 604-171, 2006.

[26] R. S. Sobel and P. T. Leeson, "Government response to Hurricane Katrina: A public choice analysis," Public Choice, vol. 127, pp. 55-73, 2006.

[27] M. Orie and W. R. Stahel, "Geneva reports, risk and insurance research: insurers' contribution to disaster reductions-a series of case studies," the Geneva Association, 2013

[28] E. O. M. Kerjan, "Catastrophe economics: the national flood insurance program," Journal of Economic Perspectives, vol. 24, no. 4, pp. 165-186, 2010.

[29] Federal Emergency Management Agency. (FEMA) (2013). Flood Insurance Reform Act 2012. [Online]. Available: http://www.fema.gov

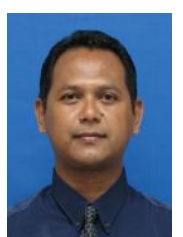

Mohamad Sukeri Khalid is a senior lecturer at School of Government, College of Law, Government and International Studies, Universiti Utara Malaysia. He obtained a doctoral degree from the Heriot-Watt University, Edinburgh UK. Before joining academia, the author was involved with industry for 5 years. His job was based more in property management and property development. After gaining practical experience in industry, the author developed his career as an academician with Universiti Utara Malaysia in 1999. The author's research interest is directed more on property market analysis, property development, property management, property economics and research into entrepreneurship. He is actively involved in teaching, research, publication and community works.

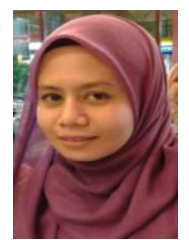

Shazwani Binti Shafiai was born at Kampung Banggol Sena, Mata Ayer, Perlis, Malaysia on December 9, 1986. The author graduated with bachelor of public management and master of public management from Universiti Utara Malaysia, Sintok Kedah in 2010 and 2012 respectively. The author is currently pursuing her $\mathrm{PhD}$ at the same university and the major fields of her study a Public Management. She is currently a research assistant attached to the School of Multimedia Technology and Communication, Universiti Utara Malaysia. 